\title{
YOUTHFUL OFFENDERS AND ADULT COURTS: PROSECUTORIAL DISCRETION vs. JUVENILE RIGHTS
}

Despite the much-commented-upon shortcomings of the juvenile justice system, ${ }^{1}$ a youth often finds it to his advantage to be proceeded against as a juvenile rather than as an adult. Under virtually all state ${ }^{2}$ and federal $^{3}$ statutes, a youth found delinquent by a juvenile or family court can be incarcerated only until his twenty-first birthday, cannot be mixed in jail with adult offenders, does not face the loss of civil rights after incarceration, and does not have an arrest or conviction placed permanently on his record for possible use in future sentencing or for possible disqualification from future public employment-in short, is entitled to a far better opportunity for rehabilitation than the convicted adult. ${ }^{4}$ Accordingly, the criteria according to which youths are selected for prosecution as juveniles rather than as adults are of vital significance to affected youths.

If a state sets a reasonable age, such as eighteen, as a dividing line between adult and juvenile status, and prosecutes only those over eighteen as adults, there seems to be no serious constitutional flaw in the selection process. ${ }^{\overline{5}}$ However, many states and the federal government have enacted statutes which differentiate among youths of the same age. ${ }^{6}$ The apparent rationale of such statutes is that, weighing society's need for protection against the benefit a youth might derive from special rehabilitative treatment, some youths of one age group should be given an opportunity to benefit from juvenile treatment, while other youths of the same age are too incorrigible to respond to such treatment, and if mixed with the former group would only impede

1 See, e.g., Handler, The Juvenile Court and the Adversary System: Problems of Function and Form, 1965 Wrs. L. Rev. 7.

2 See, e.g., PA. Stat. ANN. tit. 11, §§ 243-45, 256, 261 (1965).

3 See, e.g., 18 U.S.C. \$§ 5031-37 (1970).

4 See Kent v. United States, 383 U.S. 541, 556-57 (1966). See also Kemplen v. Maryland, 428 F.2d 169 (4th Cir. 1970), in which the petitioner had already served his sentence but nonetheless sought a writ of habeas corpus, seeking to remove his criminal conviction from his record on the grounds that he should have been proceeded against as a juvenile.

Treatment as a juvenile may, however, result in severe disadvantages. The most famous witness to such disadvantages is Gerald Gault, who was committed for six years-the duration of his minority-for an act for which an adult could have been sentenced to a maximum of two months. See In re Gault, 387 U.S. 1 (1967).

${ }^{5} \mathrm{~A}$ cutoff line set at age 16 would also seem constitutionally unassailable, although one might argue that-given the avowed rehabilitative purposes of juvenile courtssuch a youthful cutoff would be impermissibly arbitrary, or that Kent v. United States, 383 U.S. 541 (1966), constitutionalized a cutoff at 18, see notes 9-16 infra \& accompanying text. This Comment proceeds upon the assumption that such a lowering of the cutoff line would comport with due process requirements. Cf. note 30 infra.

6 For a comprehensive treatment of statutes concerning transfers from juvenile to adult courts, see Mountford \& Berenson, Waiver of Jurisdiction: The Last Resort of the Juvenile Court, 18 U. KAN. L. REV. 55 (1969). 
efforts at reform. ${ }^{7}$ Given the wide variations in our dual systems of justice, ${ }^{8}$ there arises a serious constitutional question as to what procedural standards must be observed in deciding whether a youthful offender will be accorded juvenile or adult status.

In Kent v. United States ${ }^{\theta}$ the Supreme Court examined a District of Columbia statute that allowed a family court judge to transfer jurisdiction of any youth between sixteen and eighteen to the adult court after "full investigation."10 Without such a transfer, a youth would be treated as a juvenile; with the transfer, he would enter the adult court system. In construing the statute, ${ }^{11}$ the Kent Courtwithout pausing to look to legislative history or other parts of the statutory scheme-interpreted "full investigation" to require that there be a hearing at which the youth would be represented by counsel, ${ }^{12}$ that all social records relied upon by the judge be available to the youth's attorney, and that the judge issue a written statement of his findings. Because it seems clear beyond doubt that the court was deliberately interpreting the statute to sidestep possible constitutional infirmities, ${ }^{13}$ the ultimate relevance of the decision may have initially been uncertain. ${ }^{14}$ However, any doubt that Kent established a constitutional principle should have been effectively removed by the language and holding in In re Gault, ${ }^{15}$ in which the Court held that assistance of counsel at waiver proceedings was required by due process. Most subsequent courts have thus interpreted Kent and Gault, taken together, as establishing minimum constitutional rights of juveniles at waiver hearings. ${ }^{16}$

7 See Cox v. United States, 473 F.2d 334, 343 (4th Cir. 1973).

${ }^{8}$ As one judge phrased it:

The Family Court is more than just another judicial body; it is another system of justice with different procedures, a different penalty structure, and a different philosophy of rehabilitation.

United States v. Bland, 472 F.2d 1329, 1348 (D.C. Cir. 1972) (J. Skelly Wright, J., dissenting), cert. denied, 93 S. Ct. 2294 (1973).

383 U.S. 541 (1966).

10 See id. at 547; D.C. Code ANN. \& 11-1553 (1967).

11 To construe the statute, the Court was forced to depart from its usual practice of not interpreting local statutes for the District of Columbia. See 383 U.S. at 568 (dissenting opinion).

12 For an explanation of the Court's precise holding as to appointment of counsel, see note 48 infra.

13 The Court observed that it had not in the past "deferred to decisions on local law where to do so would require adjudication of difficult constitutional questions." 383 U.S. at 557 n.27.

14 Compare Paulsen, Kent v. United States: The Constitutional Context of Juvenile Cases, 1966 Sup. Cr. Rev. 167, with Comment, Criminal Offenders in the Juvenile Court: More Brickbats and Another Proposal, 114 U. PA. L. REv. 1171 (1966).

15387 U.S. 1 (1967). The Court noted that although its decision in Kent turned upon statutory language, it had emphasized "the necessity that the basic requirements of due process and fairness be satisfied in such proceedings." Id. at 12, quoting Kent v. United States, 383 U.S. 541, 553 (1966). Later, it reiterated as a constitutional requirement the Kent view that a waiver hearing must meet due process standards. 387 U.S. at $30-31$.

18 See Powell v. Hocker, 453 F.2d 652, 654 (9th Cir. 1971). For an exhaustive col- 
If, indeed, Kent was constitutionally based, identical or similar requirements of procedural due process should remain applicable if a prosecutor, rather than a judge, is charged with determining whether a youthful offender is to be classified as a juvenile or as an adult. A youth's right to juvenile treatment would seem unaffected by a change in decisionmakers; the impact of classification on him is the same, regardless of which public official is responsible.

The Supreme Court noted probable jurisdiction in 1969 to consider related issues ${ }^{17}$ but dismissed the appeal. ${ }^{18}$ In Cox $v$. United States ${ }^{19}$ however, the Fourth Circuit, sitting en banc, confronted the issue. Reversing a three-judge panel, it held constitutional a statute which allowed the Attorney General to determine-without benefit of a hearing-whether a youth alleged to have violated a "law of the United States not punishable by death or life imprisonment"20 should be treated as a juvenile or as an adult. In so doing, the court reaffirmed its prior holding in Kemplen v. Maryland ${ }^{21}$ that a juvenile court could not transfer jurisdiction of a youth without a hearing, at which the youth was represented by counsel. Nonetheless, it distinguished a similar prosecutorial decision of identical effect, noting that " $[\mathrm{e}] \mathrm{ffects}$... are not the sole measure of the reach of the Bill of Rights"22 and reasoning that prosecutorial discretion has traditionally been unencumbered by due process requirements. ${ }^{23}$ It concluded that the prosecutor's decision whether to prosecute an offender as an adult is analytically comparable to typical charging decisions which, in the absence of invidious discrimination, are within his unrestrained discretion. ${ }^{24}$ The court indicated that as long as Congress might reasonably delegate to

lection of relevant cases, see United States ex rel. Turner v. Rundle, 438 F.2d 839, 842 n.11 (3d Cir. 1971).

17 DeBacker v. Brainard, 393 U.S. 1076 (1969).

18396 U.S. 28 (1969). The case presented the issue of the constitutionality of unrestrained prosecutorial discretion to classify youthful offenders. The Court dismissed the appeal, in part because none of the lower state courts that heard the case passed specifically on the issue. $I d$. at 32 .

For another cursory pre-Kent resolution of the issue, see United States v. Verra,

203 F. Supp. 87 (S.D.N.Y. 1962).

19473 F.2d 334 (4th Cir. 1973).

20 The statute reads, in pertinent part:

A juvenile alleged to have committed one or more acts in violation of a law of the United States not punishable by death or life imprisonment, and not surrendered to the authorities of a state, shall be proceeded against as a juvenile delinquent if he consents to such procedure, unless the Attorney General, in his discretion, has expressly directed otherwise.

18 U.S.C. $\$ 5032$ (1970).

21428 F.2d 169 (4th Cir. 1970). The court's decision rested upon the right to counsel, as well as upon due process grounds. This Comment deals only with the due process argument.

22473 F.2d at 336.

23 Id. The Cox court thus chose to ignore the contrast between a decision to try a youthful offender as an adult and other, more typical, prosecutorial decisions; as well as the tradition that waiver decisions are not for prosecutors. See id. at 341 (majority opinion of three-judge panel).

24 See Oyler v. Boles, 368 U.S. 448 (1962). 
the Attorney General the determination of the youth's status, the youth would have no right to a hearing.

The same issue-whether a prosecutor must comply with due process in determining a youthful offender's adult status-was presented with only a slightly different twist in United States v. Bland. ${ }^{25}$ There, the statute involved ${ }^{26}$ was an amended version of the statute interpreted by the Supreme Court in Kent, ${ }^{27}$ and represented a clear effort to avoid the mandates of Kent and avert the necessity of a hearing. ${ }^{28}$ It thus defined a juvenile as any youth under eighteen-with the exception of a youth over sixteen charged by the prosecutor with any of a list of serious felonies. ${ }^{29}$ Whether a youth would be deemed juvenile or adult would depend solely on the initial charge, regardless of the eventual verdict. As long as there existed probable cause to charge a youth with any of the listed felonies, the prosecutor, by choosing between that charge and a lesser offense, would have discretion in determining whether or not the youth would be prosecuted as an adult, without the guidance of the hearing which Kent found constitutionally required of a judge. ${ }^{30}$

25472 F.2d 1329 (D.C. Cir. 1972), cert. denied, 93 S. Ct. 2294 (1973).

26 D.C. Code ANN. § 16-2301(3) (A) (Supp. V, 1972).

27 D.C. CODE ANN. § 11-1553 (1967).

28 The evasion seems to have been remarkably successful. The majority of the court failed to address itself to Kent's holding anywhere in the body of its opinion. See 472 F.2d at 1339 n.1 (J. Skelly Wright, J., dissenting).

20 The statute reads, in pertinent part:

(3) The term "child" means an individual who is under 18 years of age, except that the term "child" does not include an individual who is sixteen years of age or older and-

(A) charged by United States attorney with (i) murder, forcible rape, burglary in the first degree, robbery while armed, or assault with intent to commit any such offense, or (ii) an offense listed in clause (i) and any other offense properly joinable with such an offense;

(B) charged with an offense referred to in subparagraph (A) (i) and convicted by plea or verdict of a lesser included offense . . . .

D.C. CoDe ANN. \& 16-2301(3) (Supp. V, 1972).

30 Since a prosecutor cannot be presumed to be more capable of arriving at a correct classification decision than a judge, the statutes considered in Bland and Cox, like that disapproved in Kent, deprive youthful offenders of individualized consideration of their disposition and ability to be rehabilitated. Classification by charge, as in Bland, is made particularly objectionable by its reversal of the traditional presumption of innocence. See 472 F.2d at 1337-38.

Allowing unbridled prosecutorial discretion creates the maximum possibility of irrational application of the statute. The prosecutor will be able to selectively forgive youths accused of felonies, without even the benefit of the relevant information provided by a simple due process hearing. Moreover, the legislative history of the Bland statute demonstrates fairly conclusively that even if the Attorney General charges the youth with one of the enumerated crimes and then refuses to prosecute, the juvenile court can then take jurisdiction. H.R. REP. No. 907, 91st Cong., 2d Sess. 50 (1970). This fact was noted by the lower court, United States v. Bland, 330 F. Supp. 34, 36 (D.D.C. 1971), and by Judge Wright in dissent, 472 F.2d at $1341 \mathrm{n} .2$, but was ignored by the Bland majority.

The arbitrariness of this scheme is not diminished by the observation that a state may elect to set an inflexible dividing line between adult and juvenile status at 16 , and thus sweep rehabilitable youths into the adult system. Most significantly, such a scheme would not be subject to abusive exercise of prosecutorial discretion. The fact that a benefit need not be made available by the legislature in the first instance is no excuse for 
A District of Columbia Circuit majority found it consistent with Kent to hold the Bland statute constitutional. Like the Fourth Circuit in Cox, it placed the prosecutor's determination within the category of prosecutorial discretion. As added justification for its conclusion, it reasoned that a youth between sixteen and eighteen is neither a juvenile nor an adult until charged, and thus is not divested of a right or privilege when charged with one of the enumerated felonies, since there exists no transfer of jurisdiction to which the procedural guidelines of Kent could apply.

Thus, the Supreme Court's subsequent denial of Bland's petition for a writ of certiorari represented a quiet sidestepping of large and substantial constitutional questions concerning the proper scope of prosecutorial discretion and the proper safeguards to be accorded to the juvenile status of a youthful offender..$^{31}$

\section{Prosecutorial Discretion}

Because of practical limitations on prosecutorial resources, and because no statute or manual can possibly guide a prosecutor to fair results in all conceivable charging situations, there has emerged a tradition favoring broad prosecutorial discretion. Courts have reasoned that, so long as probable cause links a defendant with a crime, the defendant has no right not to be charged. ${ }^{32}$ Therefore, a prosecutor is allowed virtually unrestrained choice in his decision whether to prosecute $^{33}$ under what statute to prosecute, ${ }^{34}$ and whether to accept a

denying a prospective beneficiary an adequate determination of his entitlement to it when the possibility does exist. See notes $41-42$ infra \& accompanying text.

While an age-based classification provides an arbitrary cutoff for juvenile jurisdiction, it at least is supported by the weight of tradition. Moreover, even if a state could theoretically lower the juvenile line to age 16 and thus sweep in more rehabilitable offenders, the harsh effect on rehabilitable youths makes that step unlikely.

If the Bland statute were to force a prosecutor to prosecute as adults all offenders chargeable with felonies, the constitutional vice currently inherent in the statute might be reduced or eliminated. Again, this new provision would result in increased harshness toward youthful offenders, and might run counter to the rehabilitative goals of the juvenile justice system. As a practical matter, however, this very harshness would make a state consider carefully before taking such a measure given the impact it might have on defendants a prosecutor might wish to favor.

For another unreasonable legislative classification, see Long v. Robinson, 436 F.2d 1116 (4th Cir. 1971), aff'g 316 F. Supp. 22 (D. Md. 1970) (juvenile status turned on whether youth came from urban area).

31 Bland v. United States, 93 S. Ct. 2294 (1973) (Douglas, Brennan, \& Marshall, JJ., dissenting).

32 See, e.g., Beauregard v. Wingard, 362 F.2d 901 (9th Cir. 1966).

${ }^{33}$ See Powell v. Katzenbach, 359 F.2d 234 (D.C. Cir. 1965), cert. denied, 384 U.S. 906 (1966).

34 See, e.g., Hutcherson v. United States, 345 F.2d 964 (D.C. Cir.), cert. denied, 382 U.S. 894 (1965). In Hutcherson, the prosecutor had a choice of prosecuting under two separate statutes. Fis choice largely determined the sentence of the defendant, as there was a wide variance in the statutory penalties. Yet the court found no greater usurpation of the judicial sentencing function than that normally inherent in a prosecutor's selection of charges, and rejected dissenting Judge Bazelon's attempt to bridle prosecutorial discretion by importing charging guidelines. 
guilty plea to a lesser crime..$^{35}$ Selective enforcement is improper only if based on an "unjustifiable standard such as race, religion, or other arbitrary classification," 36 and a defendant must make out a prima facie case of invidious discrimination before a court will review the prosecutor's decision. ${ }^{37}$ Prosecuting a defendant because of his radical leanings ${ }^{38}$ or intensively investigating a defendant suspected of a role in organized crime in an unrelated matter ${ }^{39}$ have been held valid exercises of discretion. While giving full scope to this doctrine, it is important to remember that such discretion, properly considered, is merely the expression of administrative necessity and not a distinct substantive or procedural right of the prosecutor. It negates the assertion that any particular charging decision is unlawful due to arbitrariness or improper motive, and expresses the court's nonrecognition of any countervailing interest of the defendant in the decision per se; but it should not be construed to override other independent rights of the defendant.

In both Bland and Cox, the courts held that the prosecutor's determination whether to treat a youth as an adult is a similar matter properly within prosecutorial discretion. To hold it within prosecutorial discretion to charge a defendant with a lesser offense than that for which there is probable cause means that the defendant has no right protected by the guarantees of due process or equal protection to be charged with that lesser offense; to hold that the determination whether a youth should be prosecuted as an adult is within prosecutorial discretion means that the youth has no right to be treated as a juvenile. Prosecutorial discretion is not in itself a factor merely to be balanced against other things; instead, it is a conclusion contrary to the conclusion that a due process right exists. ${ }^{40}$ Similarly, a finding that a right

35 See, e.g., Newman v. United States, 382 F.2d 479 (D.C. Cir. 1967).

${ }^{36}$ Oyler v. Boles, 368 U.S. 448,456 (1962). (1967).

37 See, e.g., People v. Gray, 254 Cal. App. 2d 256, 265-67, 63 Cal. Rptr. 211, 217-18

It has been argued that prosecutorial discretion is constitutionally mandated by the grant of law enforcement power to the executive branch, U.S. CoNsT. art. II, \$ 3. See United States v. Cox, 342 F.2d 167, 171-72 (5th Cir.), cert. denied, 381 U.S. 935 (1965). But limited judicial review solely for the purpose of determining whether equal protection has been denied would not seem to interfere with legitimate executive discretion. See Bland v. United States, 93 S. Ct. 2294 (1973) (Douglas, Brennan \& Marshall, JJ., dissenting); K. Davis, Discretionary Jusxice 188-214 (1969). See also Hutcherson v. United States, 345 F.2d 964, 970, 975-77 (D.C. Cir.) (Bazelon, J., concurring and dissenting), cert. denied, 382 U.S. 894 (1965).

38 See, e.g., Dear Wing Jung v. United States, 312 F.2d 73 (9th Cir. 1963).

${ }^{39}$ See, e.g., United States v. Socco, 428 F.2d 264, 271 (9th Cir.), cert. denied, 400 U.S. 903 (1970).

40 There is considerable semantic difficulty at this point. One might reasonably say that a matter is properly within a prosecutor's discretion, provide for only scant review of his decisions, and still require that he comply with certain standards in reaching his decision. Thus, "prosecutorial discretion" and defendants' rights would not be antithetical, but fully reconcilable. This was essentially the view of the Cox three-judge panel and Justice Wright's Bland dissent. See 473 F.2d at 341: "We emphasize that our decision does not rest on the [conclusion] that this is not a prosecutorial decision"; $472 \mathrm{~F} .2 \mathrm{~d}$ at 1342: "The issue . . . is not whether the prosecutor should be permitted to make 
to a due process hearing exists would negate the validity of overriding discretion. And while one may have no right not to be charged or to be charged with a particular offense, juvenile status is a privilege conferred by statute.

Privileges granted by the government have been recently protected from arbitrary divestment. ${ }^{41}$ Just as Kent and Gault protect juvenile status from judicial divestment, the Supreme Court has explicitly held in Goldberg $v$. Kelly $y^{42}$ that a welfare recipient has a property interest in continued benefits which so outweighs governmental interests in administrative efficiency that even a temporary suspension of benefits must comport with due process. A youth's interest in juvenile treatment-with its obviously significant implications for his liberty-is as much within the protection of the fifth and fourteenth amendments as is the welfare recipient's property interest in continued benefits.

According to the majority's analysis in Bland, however, the right to be proceeded against as a juvenile does not vest until the prosecutor has made his decision: a youth between sixteen and eighteen is neither an adult nor a juvenile until charged by the prosecutor. ${ }^{43}$ In Kent, on the other hand, the judge was divesting a youth already defined as a juvenile of the resultant privileges. This suggested distinction between the cases becomes more plausible if within the relevant age group juvenile status is the exception, adult treatment the rule; it might then follow that a correct analogy is not between cessation of juvenile status and loss of welfare benefits, but between denial of juvenile status and denial of an initial application for welfare benefits.

If, however, the raison d'être of the juvenile justice system is to make special provision for youths unsophisticated in crime and rehabilitable by special treatment-and it is devilishly hard to devise an alternate rationale-then it would seem wholly irrelevant whether juvenile status had "vested," or whether few youths of the age were

waiver decisions, but ... how he should go about making those decisions" (footnote omitted).

Unfortunately, perhaps for the very reason that other cases involving "prosecutorial discretion" have not involved clashes between discretion and cognizable rights of the defendant, the Cox and Bland majorities use the term as necessarily antithetical to due process hearing requirements.

41 For a compelling argument that a constitutional distinction between "rights" and "privileges," invoked in the past to preclude individuals in the public sector from protecting themselves against arbitrary governmental action, is illogical and no longer viable, see Van Alstyne, The Demise of the Right-Privilege Distinction in Constitutional Law, 81 HARV. L. REv. 1439 (1968).

42397 U.S. 254 (1970). See also Bell v. Burson, 402 U.S. 535 (1971).

43 The Cox court could have reached an identical result by saying that Cox became an adult or juvenile only after the Attorney General determined which he was.

It may be observed that Judge Wright, in dissent, adopts the majority's reasoning and still finds a divestiture under the Bland statute. 472 F.2d at 1343-44. But it is largely immaterial whether Judge Wright was correct, for statutory amendments could clearly eliminate the divestiture. It is more important to note the basic irrelevance of the divestiture argument, 
accorded that status. The youth's all-important disposition to be helped remains the same whether he is legally classified as adult, juvenile, or something in between. If the legislative classification does not preclude treating the youth as a juvenile, then, irrespective of legal labels, he should be entitled to the elements of due process before being classified as an adult.

This conclusion seems confirmed by the suggested welfare analogy. Although nothing in the majority opinion in Goldberg makes it clear that one has a right to due process when initially applying for welfare benefits, the dissent to a companion case raised the possibility. ${ }^{44}$ Initial applications for public housing ${ }^{45}$ and liquor licenses ${ }^{46}$ have been held within the scope of due process. There seems no logical reason why juvenile status is a lesser privilege not entitled to similar protections, to be overridden by a need for prosecutorial discretion. Finally, even if a distinction between discontinuance and denial of a benefit may reasonably be implied in areas-such as welfare-where the "vesting" of a right may be thought to generate a form of reliance or dependence, no such distinction is rational in the situations under discussion. Whether juvenile status is conferred in a judge's discretion or automatically, subject to divestment, its real benefits attach only with the commencement of judicial proceedings. Bland and Kent are indistinguishable in this regard. The relevant question, thus, is not whether due process requirements should apply to determination of juvenile status, but merely what form they should take.

\section{Contours of DUE Process}

The Kent court mandated procedural due process, yet in no way indicated what had to be shown or examined at such a hearing. ${ }^{47}$ Despite this silence, it has been assumed that the relevant fact to be examined is the likelihood of rehabilitating the youth, balanced against society's need for protection..$^{48}$ It is more difficult, however, to conclude what exact procedural trappings are required by due process.

Kent included among the requisites of due process that a youth

44 Wheeler v. Montgomery, 397 U.S. 280, 284-85 (1970) (Burger, C.J., dissenting).

45 Holmes v. New York City Housing Authority, 398 F.2d 262, 265 (2d Cir. 1968). The court admonished that "due process requires that selections among applicants [for public housing] be made in accordance with 'ascertainable standards." (quoting Hornsby v. Allen, 326 F.2d 605, 612 (5th Cir. 1964)).

46 Hornsby v. Allen, 326 F.2d 605 (5th Cir. 1964) (rejecting the argument that, since sales of liquor were deemed a privilege, the licensing authority had unreviewable discretion to grant or deny licenses).

47 This paradox is noted in Comment, Criminal Offenders in the Juvenile Court: More Brickbats and Another Proposal, 114 U. PA. L. REV. 1171 (1966).

48 See Paulsen, Kent v. United States: The Constitutional Context of Juvenile Cases, 1966 Sur. Cr. REv. 167, 182. The three-judge panel in Cox also determined, on the basis of legislative history (though without any specific references), that a transfer hearing must weigh a youth's best interests against the interests of society. $473 \mathrm{~F} .2 \mathrm{~d}$ at 342. Cf. Bell v. Burson, 402 U.S. 535 (1971). 
have an attorney or have one appointed for him, ${ }^{49}$ that there be a hearing, that the attorney have access to all records before the court, and that there be written findings sufficient for a reviewing court to find that there had been a full investigation. ${ }^{50}$ These requirements, however, were all predicated upon the assumption that the waiver determination would be made by a judge. Can a determination by a prosecutor be made consistent with due process? If so, must the requirements be changed?

There seems to be no reason why a prosecutor cannot make a waiver determination in accordance with due process. Before its decision was vacated by the court en banc, the three-judge panel in Cox had so held; and Goldberg v. Kelly offers additional precedent for the assertion that the Attorney General or his delegate possesses sufficient impartiality for due process purposes. While indicating that an impartial decisionmaker was imperative to determine whether the cessation of welfare benefits was justified, ${ }^{51}$ Goldberg held that a superior official in the welfare administration-even one previously involved in the present case, so long as he had not participated in making the decision under review-would be an acceptable decisionmaker.

The Goldberg holding is not exact precedent, because a court might well require greater safeguards in a hearing affecting personal liberty than in one which involves property interests, ${ }^{52}$ but may nonetheless be persuasive. It does seem clear, however, that even conceding the decisionmaking to the Attorney General's office, the prosecuting attorney himself could not be final arbiter in a hearing to determine the youth's status, for he would have made the initial decision to prosecute the youth and thus could scarcely qualify as impartial.

The three-judge panel in Cox did not require a hearing, finding it sufficient for due process purposes that a copy of the request for adult prosecution be given to the youth and his counsel, that they be given an opportunity to write a rebuttal letter, and that the prosecutor's decision be reviewable under the Administrative Procedure Act. ${ }^{53}$ It is uncertain whether these requirements would suffice; for Goldberg explicitly stressed the importance of a hearing with confrontation and cross-examination of witnesses, ${ }^{54}$ and Kent, while silent on the issue

49 Because Morris Kent had his own attorney, the Court's requirement that an attorney be appointed is, strickly speaking, only dictum. Yet it seems crystal clear from Kent and Gault that counsel is now required. See Schornhorst, The Waiver of Juvenile Court Jurisdiction: Kent Revisited, 43 IND. L.J. 583 (1968).

50 It seems a reasonable assumption that these are constitutionally mandated. See notes 9-16 supra \& accompanying text.

51 Cf. Jones v. Robinson, 440 F.2d 249 (D.C. Cir. 1971) (establishing due process requisites for mental patients accused of crime, including a requirement that wherever possible the decisionmaker have no prior connection with the incident at hand).

52 In the words of the Court in Bell v. Burson, 402 U.S. 535, 540 (1971), "[P]rocedures adequate to determine a welfare claim may not suffice to try a felony charge."

53 5 U.S.C. $\$ \$ 551-59,701-06$ (1970).

54397 U.S. at 271. 
of confrontation of witnesses, also required a hearing. Whether a hearing is always required in juvenile status determinations, is unclear; it might only be absolutely required when, as in Cox, a distant official in the Justice Department, unfamiliar with the case, is making the determination. It does seem clear, however, that if one takes seriously the premises fundamental to the juvenile justice system-that the juvenile courts exist for the benefit of rehabilitable youthful offenders-due process requires that a prosecutor's discretion to select offenders for adult treatment be checked by whatever procedures will guarantee individual examination of a defendant's disposition.

\section{CONCLUSTON}

The recent decisions in Cox and Bland expand the concept of prosecutorial discretion, and allow a significant privilege of a rehabilitable youthful offender to be overridden by a doctrine developed for prosecutorial convenience. In so doing, the cases allow evasion of the seemingly clear mandates of Kent, and ignore important due process protections established in Goldberg.

The Supreme Court's denial of certiorari in Bland suggests an unfortunate unwillingness to confront substantial constitutional questions. It must be hoped that in time the Court will end its silence, confront this clash between prosecutorial discretion and the rights of offenders, and prevent a doctrine aimed at ensuring prosecutorial fairness and flexibility from shielding potentially arbitrary and inequitable handling of juvenile offenders. 